University of Nebraska - Lincoln

DigitalCommons@University of Nebraska - Lincoln

Faculty Papers and Publications in Animal

Science

Animal Science Department

1999

\title{
Evaluation of Nitrogen and Organic Matter Balance in the Feedlot as Affected by Level and Source of Dietary Fiber
}

\author{
S. Bierman \\ University of Nebraska-Lincoln \\ Galen Erickson \\ University of Nebraska-Lincoln, gerickson4@unl.edu \\ Terry Klopfenstein \\ University of Nebraska-Lincoln, tklopfenstein1@unl.edu \\ Rick A. Stock \\ University of Nebraska-Lincoln, rstock3@Unl.edu \\ D. H. Shain \\ University of Nebraska-Lincoln
}

Follow this and additional works at: https://digitalcommons.unl.edu/animalscifacpub

Part of the Animal Sciences Commons

Bierman, S.; Erickson, Galen; Klopfenstein, Terry; Stock, Rick A.; and Shain, D. H., "Evaluation of Nitrogen and Organic Matter Balance in the Feedlot as Affected by Level and Source of Dietary Fiber" (1999). Faculty Papers and Publications in Animal Science. 460.

https://digitalcommons.unl.edu/animalscifacpub/460

This Article is brought to you for free and open access by the Animal Science Department at DigitalCommons@University of Nebraska - Lincoln. It has been accepted for inclusion in Faculty Papers and Publications in Animal Science by an authorized administrator of DigitalCommons@University of Nebraska - Lincoln. 


\title{
Evaluation of Nitrogen and Organic Matter Balance in the Feedlot Affected by Level and Source of Dietary Fiber ${ }^{1}$
}

\author{
S. Bierman, G. E. Erickson, T. J. Klopfenstein'2, R. A. Stock ${ }^{3}$, and D. H. Shain \\ University of Nebraska, Lincoln 68583-0908
}

ABSTRACT: A trial was conducted to determine the effect of level and source of dietary fiber on $\mathrm{N}$ and OM excretion by cattle on finishing diets. One hundred twenty steers were stratified by weight and allotted to one of the following treatments: 7.5\% roughage $(7.5 \% \mathrm{R})$, wet corn gluten feed (WCGF; $41.5 \%$ of dietary DM), and all-concentrate (All Con) diet. Cattle were fed for $87 \mathrm{~d}$ during the summer with $23.7 \mathrm{~m}^{2}$ of pen area per animal. Steers fed the WCGF diet had heavier final weights, greater DMI, and higher ADG $(P<.01)$ than the $7.5 \% R$ and All Con treatments. Steers fed All Con had Iower $(P<.01)$ DMI than the other two treatments. Nitrogen and OM mass balances in the feedlot were quantified. Main components were nutrient input, retention, and excretion. Nitrogen and OM intake of steers fed WCGF were greater $(P<.05)$ than those of steers fed the other treatments. The WCGF treatment had a greater percentage of fecal $\mathrm{N}$ output $(\mathrm{P}<.05)$. The All Con treatment had a greater $(\mathrm{P}<.01)$ percentage of urinary $\mathrm{N}$ than WCGF and $7.5 \% \mathrm{R}$ diets. Steers fed the WCGF treatment excreted more $(P<.01)$ OM compared with the other treatments, which led to more $\mathrm{N}$ and $\mathrm{OM}$ being removed in manure at cleaning. The All Con treatment had more $(P<.01) \mathrm{N}$ and OM in runoff than the other treatments. Nutrition can change site of fermentation, which affects the composition of excreted material; however, total amount of $\mathrm{N}$ excreted may be more important than route of excretion in decreasing $\mathrm{N}$ losses to the environment and maximizing recovery in manure.

Key Words: Feedlots, Cattle, Manures, Nutrient Balance, Nitrogen, Fiber

O1999 American Society of Animal Science All rights reserved.

J. Anim. Sci. 1999. 77:1645-1653

\section{Introduction}

Management practices must be developed that will maintain and protect the environment while permitting confinement feeding of beef cattle. Development of diets that alter the amount and route of $\mathrm{N}$ and $\mathrm{P}$ excretion can minimize deleterious effects of animal waste on the environment.

In ruminants, the degree of hindgut fermentation is affected by dietary carbohydrate sources, which affect the total amount of fecal N and OM (Giger-Reverdin et al., 1991; Larson, 1992). Carbohydrates are degraded extensively in the rumen and small intestine. Some sources of fiber do not digest extensively in the rumen but do ferment in the hindgut. Hindgut fermentation increases fecal $\mathrm{N}$ and decreases urinary $\mathrm{N}$ excretion (Ulyatt et al., 1975).

\footnotetext{
${ }^{1}$ Published with the approval of the director as paper no. 12330 , journal ser., Nebraska Agric. Res. Div.

${ }^{2}$ To whom correspondence should be addressed.

${ }^{3}$ Current address: Cargill Corn Milling, Blair, NE.

Received August 28, 1998.

Accepted February 17, 1999.
}

It has been estimated that 50 to $75 \%$ of excreted $\mathrm{N}$ is lost before feedlot pens are cleaned (Vanderholm, 1985; Eghball and Power, 1994), thus decreasing the nutrient value of the feedlot waste. Because urea is rapidly converted to ammonia following excretion (Mobley and Hausinger, 1989), and because $97 \%$ of urine $\mathrm{N}$ is urea (Mackie et al., 1998), shifting $\mathrm{N}$ excretion from urine to feces may lower ammonia losses from feedlots. The objectives of this study were to reduce the loss of $\mathrm{N}$ from the feedlot surface by shifting the distribution of $\mathrm{N}$ from urine to feces through dietary carbohydrate source and to evaluate retention and loss of excreted $\mathrm{N}$ and $\mathrm{OM}$ from the feedlot surface.

\section{Materials and Methods}

Digestibility Trial

Three British crossbred steers with average BW of $295 \mathrm{~kg}$ were studied in a $3 \times 3$ Latin square design. Steers were assigned randomly to one of three dietary treatments, $7.5 \%$ roughage ( $\mathbf{7 . 5 \%} \mathbf{R}$ ), wet corn gluten feed ( WCGF, $41.5 \%$ of DM), and all concentrate (All Con). Diets were formulated to contain a minimum of 
$12.5 \% \mathrm{CP}, .7 \% \mathrm{Ca}, .3 \% \mathrm{P}, .7 \% \mathrm{~K}, 11 \mathrm{mg} / \mathrm{kg}$ of Tylan (Elanco Animal Health, Indianapolis, I N) and $28 \mathrm{mg} /$ $\mathrm{kg}$ of Rumensin (Elanco Animal Health; Table 1). Steers were adapted to each finishing diet in $21 \mathrm{~d}$ using four adaptation diets. Adaptation diets contained forage:concentrate ratios of 45:55, 35:65, 25:75, and 15:85. The forage source was a 50:50 mixture (DM basis) of corn silage and alfalfa hay, with corn silage assigned a forage value of $50 \%$. Steers were given a 10-d adaptation period to the finishing diets followed by a 7-d collection period. Steers were housed individually in $1.5-\times 2.4-\mathrm{m}$ pens in a $25^{\circ} \mathrm{C}$ temperature-controlled room.

Steers were fed dietary treatments for $7 \mathrm{~d}$ in pens and then tied in stanchions for a 3-d adaptation period followed by 7-d total fecal and urine collection period. Feed intakes used for calculations were recorded $2 \mathrm{~d}$ before the collection period began and ended $7 \mathrm{~d}$ later. Total feces and urine were collected separately for $7 \mathrm{~d}$. Steers were fed every $2 \mathrm{~h}$ by automatic feeders. Steers were fed near ad libitum intake, but DMI was managed to avoid accumulation of orts after each 2-h feeding. Orts that accumulated were weighed, sampled, and frozen at $-4^{\circ} \mathrm{C}$ until they were analyzed. Fecal matter was collected in fecal collection bags. Urine was collected through rubber funnels strapped to the steers. Rubber tubing was connected to the bottom of the funnels and drained into plastic buckets placed in a pit below each steer. Urine was moved through the tubing by suction created by a vacuum. U rine was collected in a bucket containing $300 \mathrm{~mL}$ of 5 $\mathrm{N}$ sulfuric acid to prevent $\mathrm{N}$ volatilization. Twice per day, fecal bags were weighed, emptied, and $10 \%$ of feces was sampled. Once per day, urine buckets were weighed and contents were mixed and sampled. Feed ingredients were sampled during the collection period, and all fecal, urine, and feed samples were frozen at $-4^{\circ} \mathrm{C}$ until they were analyzed.

All samples were composited by animal, treatment, and period then analyzed for Kjeldahl $\mathrm{N}$ (AOAC, 1996). Composited fecal samples were dried for $24 \mathrm{~h}$ in a forced-air oven at $60^{\circ} \mathrm{C}$, ground through a 2-mm screen in a Wiley mill, and analyzed for DM (AOAC, 1996).

Data were analyzed as a Latin square design according to the GLM procedures of SAS (1990) with steer as the experimental unit.

\section{Feedlot Trial}

One hundred twenty crossbred yearling steers (336.6 $\pm .8 \mathrm{~kg}$ ) were stratified by weight and randomly assigned to one of three dietary treatments. Steers were purchased the previous fall and backgrounded on cornstalks and drylot until May 27, 1994. Dietary treatments were the same as those described in the digestibility trial (Table 1 ). Steers were adapted to the final diets similar to the digestibility trial except that steers receiving $7.5 \% \mathrm{R}$ and All Con diets were fed the same adaptation diets with corn as the grain source and a 50:50 mixture of corn silage and alfalfa hay as forage sources, and steers receiving WCGF diets were fed adaptation diets with wet corn gluten feed replacing corn. Wet corn gluten feed (15.3\% CP; $42.9 \%$ DM ) was produced by Minnesota Corn Processors (Columbus, NE) and transported to the beef feedlot (Agricultural Research and Development Center, Mead, NE). Dietary feed ingredients were collected once weekly and frozen at $-4^{\circ} \mathrm{C}$ until they were analyzed. Initial weights were the average of weights taken on two consecutive days after cattle had been adapted to finishing diets. However, to minimize variation in gut fill, a common diet was fed 5 $\mathrm{d}$ before initial weighing and feed intake was restricted to an estimated 2\% (DM basis) of body weight. Steers were implanted with Revalor-S (HoechstRoussel, Warren, NJ ) on the 2nd d that weights were taken. Steers were fed once daily with ad libitum

Table 1. Composition of diets used in digestibility and feedlot trials ${ }^{a}$

\begin{tabular}{|c|c|c|c|}
\hline \multirow[b]{2}{*}{ Ingredient } & \multicolumn{3}{|c|}{ Treatments $^{\mathrm{b}}$} \\
\hline & WCGF & $7.5 \% \mathrm{R}$ & All Con \\
\hline Dry-rolled corn & 43.5 & 78.8 & 88.8 \\
\hline Wet corn gluten feed & 41.5 & - & - \\
\hline Corn silage & 5.0 & 5.0 & - \\
\hline Alfalfa hay & 5.0 & 5.0 & - \\
\hline Molasses supplement ${ }^{C}$ & - & 6.2 & 6.2 \\
\hline \multicolumn{4}{|l|}{ Dry supplement } \\
\hline Ground corn & 2.72 & 2.45 & 1.92 \\
\hline Limestone & 1.5 & 1.4 & 1.6 \\
\hline Urea & .32 & .53 & .64 \\
\hline Salt & .30 & .30 & .30 \\
\hline Potassium chloride & - & .19 & .41 \\
\hline Animal fat & .10 & .10 & .10 \\
\hline Monensin premix ${ }^{d}$ & .02 & .02 & .02 \\
\hline Tylosin premix & .01 & .01 & .01 \\
\hline Vitamin premix ${ }^{f}$ & .01 & - & - \\
\hline Trace mineral premix ${ }^{g}$ & .02 & - & - \\
\hline \multicolumn{4}{|l|}{ Composition ${ }^{\mathrm{h}}$} \\
\hline Crude protein & 12.47 & 12.92 & 12.83 \\
\hline Degradable intake protein & 8.39 & 8.28 & 8.09 \\
\hline NDF & 28.4 & 13.6 & 9.9 \\
\hline Calcium & .70 & .70 & .70 \\
\hline Phosphorus & .33 & .25 & .25 \\
\hline Potassium & .70 & .70 & .70 \\
\hline
\end{tabular}

apercentage on a dry matter basis.

bWCGF = wet corn gluten feed diet; $7.5 \% \mathrm{R}=7.5 \%$ roughage diet; All Con $=$ all-concentrate diet.

CUrea-based molasses supplement containing 50.6\% CP, .55\% P, vitamins $(78,925 \mathrm{IU}$ of vitamin $\mathrm{A} / \mathrm{kg}, 15,789 \mathrm{IU}$ of vitamin $\mathrm{D} / \mathrm{kg}$, and 20 IU of vitamin $\mathrm{E} / \mathrm{kg})$, and trace minerals $(.37 \%$ of supplement $\mathrm{DM} ; 2.25 \% \mathrm{Fe}, 1.0 \% \mathrm{Zn}, .64 \% \mathrm{Mn}, .20 \% \mathrm{Cu}, .18 \% \mathrm{Mg}, .16 \% \mathrm{Co}$, and $.55 \% \mathrm{I})$.

d $132 \mathrm{~g}$ monensin/ $\mathrm{kg}$ of premix.

e $88 \mathrm{~g}$ of tylosin/ $\mathrm{kg}$ of premix.

${ }^{f} 15,000$ IU of vitamin A, 3,000 IU of vitamin D, and 3.75 IU of vitamin $\mathrm{E} / \mathrm{g}$ of premix.

${ }^{9} 10 \% \mathrm{Mg}, 6 \% \mathrm{Zn}, 4.5 \% \mathrm{Fe}, 2 \% \mathrm{Mn}, .5 \% \mathrm{Cu}, .3 \% \mathrm{I}, .05 \% \mathrm{Co}$.

${ }^{\mathrm{h}}$ Crude protein and phosphorus were analyzed, other nutrients were calculated; all expressed as a percentage of diet DM. 


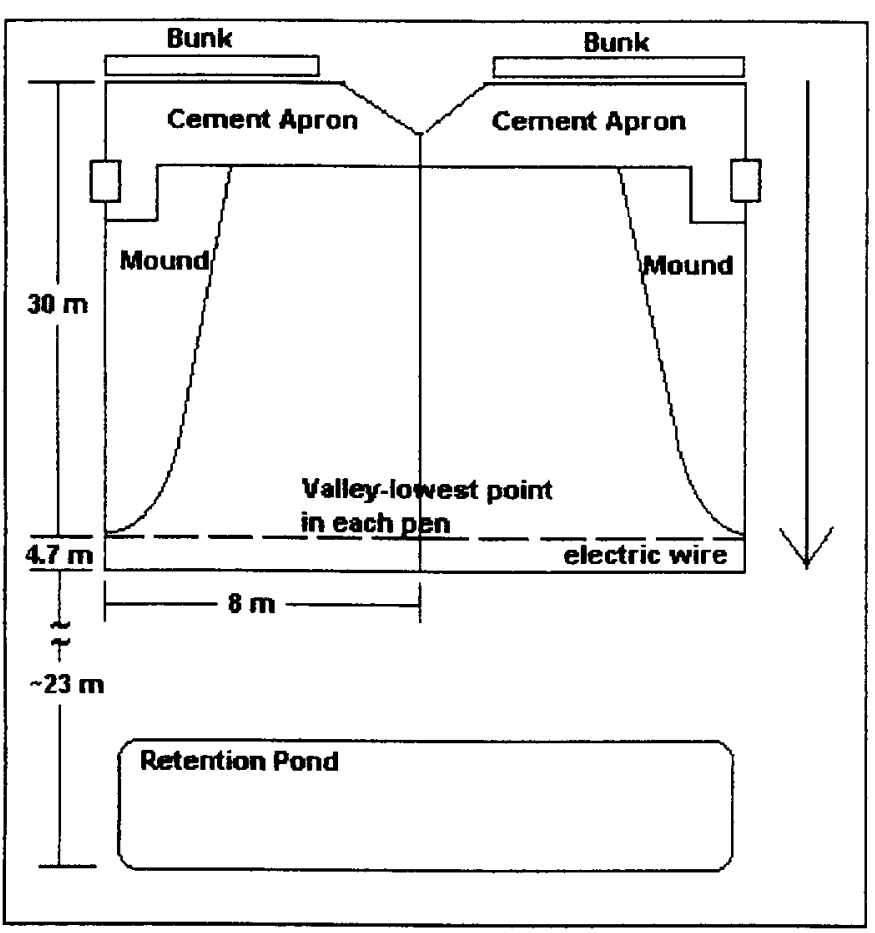

Figure 1. Diagrammatic representation of two test pens used for the 87-d collection period in the feedlot.

access to feed and water in outdoor pens. Cattle had $95 \mathrm{~cm}$ of linear bunk space and $23.7 \mathrm{~m}^{2}$ of pen space per animal.

To minimize variation in gut fill, final weights were calculated from hot carcass weight assuming 62\% dressing percentage. $\mathrm{F}$ at thickness over the 12th rib and quality grade were recorded after a 48-h chill.

Cattle were adapted to treatment diets in pens not used during the collection period. Twelve pens used during the collection period were cleaned and re mained idle for $30 \mathrm{~d}$. Three soil core samples $(15 \mathrm{~cm}$ deep) were taken from various locations within each test pen prior to cattle being placed into them. At the termination of the trial, test pens were cleaned, and three core soil samples were taken from approximately the same location within each pen.

After consuming the high-energy treatment diet for $7 \mathrm{~d}$, steers were moved to the 12 test pens on J une 27 , 1994. Cattle performance data were based on the 118-d total feeding period including adaptation to high energy, whereas the nutrient balance data were based on the 87-d collection period while cattle were in the 12 test pens (Figure 1 ). The bottom of each pen was fenced off by electric wire to avoid build-up of waste material along the fenceline where it could not be removed effectively. Pens were divided by one fenceline on top of the mound and the other in the valley between mounds. Runoff from two adjacent pens was collected into one retention pond. The adjacent pens were assigned to the same treatment. Thus, six retention ponds collected runoff from the 12 pens. Retention ponds were constructed of soil berms and lined with plastic.

Retention ponds were calibrated using a known volume of water. When a runoff event occurred, each retention pond's volume was quantified, the contents mixed manually, four samples taken, and then drained into the normal sediment basins for the feedlot. The retention ponds' maximal volume was approximately $80,000 \mathrm{~L}$ (40,000 L/pen). Weekly fecal samples from various areas in each pen were taken by hand and consisted of fresh fecal excrement without soil contamination. Soil cores, retention pond, and fecal samples were frozen at $-4^{\circ} \mathrm{C}$ until they were analyzed.

Steers were fed for $87 \mathrm{~d}$ and then removed from pens. Pens were cleaned in replication across treatments immediately after the cattle were removed by removal of waste material with minimal soil. Material was piled on the apron in the pen with a front end loader with some manual cleaning using shovels. Material was mixed, sampled, and removed from the pen and weighed. In the last replication, pens (replication four for each treatment) did not get cleaned before it rained. After the rain subsided and the surface was fairly dry, runoff was collected from the retention ponds, and pens in the last replication were cleaned, sampled, and waste material was weighed.

Feed ingredients were collected weekly, dried at $60^{\circ} \mathrm{C}$, and composited monthly. Fecal samples were composited by pen and oven-dried for $24 \mathrm{~h}$ at $60^{\circ} \mathrm{C}$, ground through a Wiley Mill (2-mm screen), and analyzed for DM, Kjeldahl N, and ash (AOAC, 1996). Composited feed ingredients were also analyzed for Kjeldahl $\mathrm{N}$ and ash. Nutrient composition of feed ingredients (Table 2) was used to calculate nutrient intakes. Retention pond samples were analyzed for DM, Kjeldahl N, and ash. Samples of waste material from cleaned pens were mixed with $5 \mathrm{~N}$ sulfuric acid to allow particles to break apart. The material was thoroughly mixed, and a representative subsample was taken. Subsamples were analyzed for DM, Kjeldahl N, and ash.

Input of $\mathrm{N}$ was calculated as $\mathrm{N}$ concentration in the respective diet times DMI. Retained N was calculated using the net protein gain equation (NRC, 1996). The difference between $\mathrm{N}$ input and calculated $\mathrm{N}$ retention in the animal was total $\mathrm{N}$ excretion. The quantity of fecal $\mathrm{N}$ was calculated as DMI multiplied by DM indigestibility (from the digestibility trial, Table 3) multiplied by the concentration of $\mathrm{N}$ in the feces. U rinary $\mathrm{N}$ was determined by difference between total $\mathrm{N}$ output and fecal $\mathrm{N}$ output. Nitrogen removed from the feedlot surface was determined as the amount of manure DM removed at cleaning multiplied by the $\mathrm{N}$ concentration of the manure. Nitrogen lost in runoff 
Table 2. Nutrient composition of dietary sources used in digestibility and feedlot trials ${ }^{\mathrm{a}}$

\begin{tabular}{|c|c|c|c|c|c|}
\hline \multirow[b]{2}{*}{ Ingredient } & \multicolumn{5}{|c|}{ Nutrient } \\
\hline & DM & $\mathrm{N}$ & $P$ & OM & $\mathrm{NDF}^{\mathrm{b}}$ \\
\hline Dry-rolled corn & 86 & 1.39 & .24 & 98.6 & 10.9 \\
\hline Wet corn gluten feed & 43 & 2.44 & .48 & 96.6 & 45.0 \\
\hline Corn silage & 32 & 1.18 & .18 & 94.9 & 48.0 \\
\hline Alfalfa hay & 88 & 2.75 & .27 & 90.9 & 46.0 \\
\hline Molasses supplement ${ }^{C}$ & 60 & 8.1 & .55 & 95.1 & - \\
\hline
\end{tabular}

aDetermined by laboratory analysis, expressed as a percentage of dry matter.

bTabular values.

CUrea-based molasses supplement containing 50.6\% CP, .55\% P, vitamins (78,925 IU of vitamin A/kg, $15,789 \mathrm{IU}$ of vitamin $\mathrm{D} / \mathrm{kg}$, and $20 \mathrm{IU}$ of vitamin $\mathrm{E} / \mathrm{kg})$, and trace minerals $(.37 \%$ of supplement DM; $2.25 \% \mathrm{Fe}, 1.0 \% \mathrm{Zn}, .64 \% \mathrm{Mn}, .20 \% \mathrm{Cu}, .18 \% \mathrm{Mg}, .16 \% \mathrm{Co}$, and $.55 \% \mathrm{I})$.

was calculated as the quantity of runoff multiplied by the $\mathrm{N}$ concentration of runoff. Nitrogen incorporated into the soil was the difference between $11.6 \mathrm{~m}^{3}$ (volume of soil in top $15 \mathrm{~cm}$ of each pen) multiplied by the $\mathrm{N}$ concentration of the soil following the trial vs the $\mathrm{N}$ concentration before cattle were in the pens. Amount of $\mathrm{N}$ volatilized was the difference between the amount of $\mathrm{N}$ excreted and the amount removed in manure, runoff, and $\mathrm{N}$ incorporated into the soil. Fecal OM equaled DMI multiplied by DM indigestibility (from digestibility trial, Table 3) multiplied by the concentration of OM in the feces.

Performance, carcass, and nutrient data were analyzed as a completely randomized design according to the GLM procedures of SAS (1990) with pen as the experimental unit. The experimental unit for runoff data was the retention pond. Therefore, runoff data were analyzed with two replications. Treatment was the model effect for all analyses. Mass balance data were analyzed based on the quantity of nutrients, expressed as kilograms per animal for the collection period $(87 \mathrm{~d})$.

\section{Results and Discussion}

\section{Digestibility Trial}

Nitrogen intake was lower $(P<.10)$ for steers fed the All Con diet than for steers on the other two treatments (Table 3 ). Nitrogen excretion was greatest $(P<.10)$ with the WCGF treatment and lowest with the All Con diet. Nitrogen digestibility was lower $(P<$ .10) with steers fed WCGF than with steers fed $7.5 \%$ $\mathrm{R}$ and All Con. No treatment difference $(\mathrm{P}>.10)$ was observed between All Con and 7.5\% R for $\mathrm{N}$ digestibility. Nitrogen excretion in feces was similar $(P>.10)$ for WCGF and $7.5 \%$ R steers, with 50 to $55 \%$ of total N excreted in the feces. Steers fed the All Con diet excreted $33 \%$ of total $\mathrm{N}$ via the feces. Dry matter digestibility was lowest $(P<.10)$ for WCGF and not significantly different between $7.5 \% \mathrm{R}$ and the All Con treatment despite numerical differences.

Nitrogen intakes were different across dietary treatments due to differences in DMI and dietary $\mathrm{N}$ composition (Tables 1 and 2). Total $\mathrm{N}$ excretion was highest for WCGF and lowest for the All Con

Table 3. DM digestibility, $\mathrm{N}$ digestibility, and routes of

$\mathrm{N}$ excretion from digestibility trial

\begin{tabular}{|c|c|c|c|c|}
\hline \multirow[b]{2}{*}{ Item } & \multicolumn{3}{|c|}{ Treatment $^{a}$} & \multirow[b]{2}{*}{ SEM } \\
\hline & WCGF & $7.5 \% \mathrm{R}$ & All Con & \\
\hline DMI, kg & 9.24 & 9.34 & 5.62 & 1.0 \\
\hline DM digestibility, \% & $71.4^{b}$ & $80.5^{c}$ & $83.5^{c}$ & 2.3 \\
\hline $\mathrm{N}$ intake, g.steer ${ }^{-1} \cdot \mathrm{d}^{-1}$ & $186.5^{\mathrm{b}}$ & $175.0^{\mathrm{b}}$ & $106.0^{c}$ & 15.1 \\
\hline $\mathrm{N}$ excreted, g.steer ${ }^{-1} \cdot \mathrm{d}^{-1}$ e & $115.4^{\mathrm{b}}$ & $88.8^{c}$ & $70.2^{d}$ & 6.0 \\
\hline Fecal $N, \%$ of excreted & $55.3^{\mathrm{b}}$ & $50.9^{b}$ & $33.1^{\mathrm{C}}$ & 4.1 \\
\hline Urinary $\mathrm{N}, \%$ of excreted & 44.7 & 49.1 & 66.9 & 4.1 \\
\hline $\mathrm{N}$ digestibility, \% & $65.2^{\mathrm{b}}$ & $74.7^{c}$ & $76.9^{c}$ & 2.6 \\
\hline $\mathrm{N}$ indigestibility, \% & 34.8 & 25.3 & 23.1 & 2.6 \\
\hline
\end{tabular}

aWCGF $=$ wet corn gluten feed diet; $7.5 \% \mathrm{R}=7.5 \%$ roughage diet; All Con $=$ all-concentrate diet.

$b, c, d$ Means within a row with unlike superscripts differ $(P<.10)$. Trends are similar between fecal and urinary $\mathrm{N}$ excretion percentages. Indigestibility was calculated as 100 minus digestibility.

eTotal excreted calculated from measured urine and fecal output. 


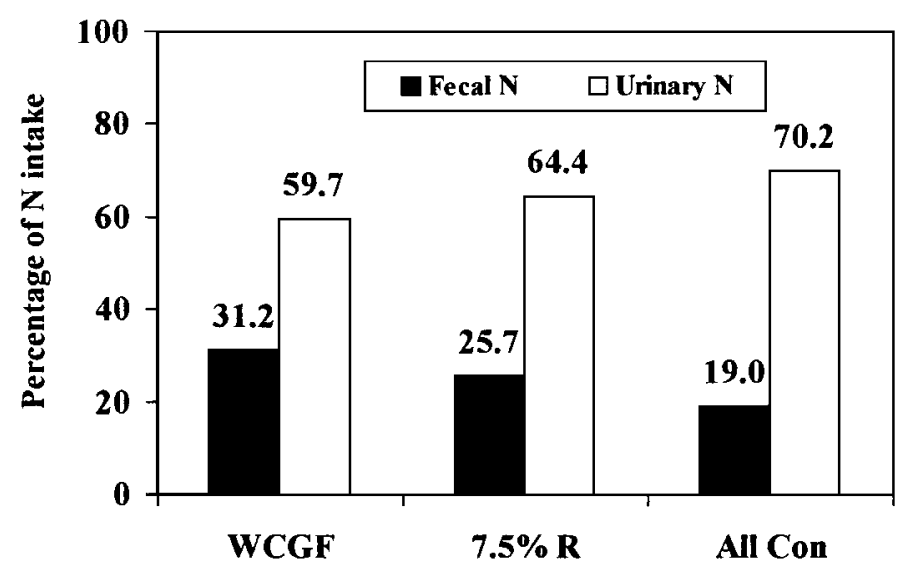

Treatments

Figure 2. Distribution of excreted $\mathrm{N}$ between feces and urine as determined during the feedlot trial, where All Con $=$ all concentrate, $7.5 \% \mathrm{R}=7.5 \%$ roughage from corn silage and alfalfa, and WCGF $=41.5 \%$ corn gluten feed with roughage. Values are expressed as percentage of $\mathrm{N}$ intake.

treatments. The high-starch diet probably reduced the amount of fermentable carbohydrate reaching the hindgut. The All Con treatment had the lowest fecal $\mathrm{N}$ excretion due to the low fiber content of the diet and, thus, had minimal hindgut fermentation (Larson, 1992). Hindgut fermentation of cellulose and hemicellulose accounts for 18 to $40 \%$ of total fiber digestion (Ulyatt et al., 1975). Therefore, feeding the WCGF diet resulted in greater $(\mathrm{P}<.10)$ fecal $\mathrm{N}$ excretion in grams/day, probably due to the hindgut fermentation.

The dietary treatments had different carbohydrate sources, and this caused variation in the distribution of excreted $\mathrm{N}$ between feces and urine. Mason et al. (1977) showed differences in the amounts of fecal and urinary $N(P<.01)$ when sheep where infused with either cellulose, starch, or pectin, indicating that the type of carbohydrate can influence the pathway for $\mathrm{N}$ excretion.

Urinary $\mathrm{N}$ accounted for 25 to $44 \%$ of the $\mathrm{N}$ intake. This range is slightly lower than yet agrees with the average $(42.8 \%)$ determined by Giger-Reverdin et al. (1991), who fed 44 diets containing various carbohydrates to goats. When urinary $\mathrm{N}$ is expressed in grams of $\mathrm{N}$ per day, steers on all treatments excreted approximately the same amount, 44 to $52 \mathrm{~g} / \mathrm{d}$. Therefore, the primary difference between the dietary treatments seems to be the amount of fecal $\mathrm{N}$ excreted. The percentage of urinary $\mathrm{N}$ from this experiment may be low due to the difficulty in collecting $100 \%$ of the urine. If less than $100 \%$ of urinary $\mathrm{N}$ was collected, then $\mathrm{N}$ retention and the percentage of $\mathrm{N}$ intake excreted as fecal $\mathrm{N}$ would be overestimated. The percentage of $\mathrm{N}$ intake that was excreted as fecal $\mathrm{N}$ ranged from 22 to $34 \%$, which is higher than results from the feedlot trial (Figure 2). However, the ranges of fecal $\mathrm{N}$ from both trials are in agreement with the average of $28.8 \%$ as determined by Giger-Reverdin et al. (1991).

\section{Feedlot Trial}

Steers on the WCGF treatment had higher ( $\mathrm{P}<$ .01) final weights, DMI, and ADG than steers on the other two treatments (Table 4). Steers on the All Con treatment had the lowest $(\mathrm{P}<.01) \mathrm{DMI}$; however, those steers were the most efficient $(P<.01)$. Steers fed $7.5 \% R$ were less efficient $(P<.10)$ than the steers fed WCGF. Steers fed $7.5 \% \mathrm{R}$ were intermediate in DMI $(P<.01)$ and gain $(P<.10)$. No differences were observed in fat thickness and quality grades.

Steers fed WCGF had greater $(P<.01) \mathrm{N}$ intakes than steers consuming 7.5\% R and All Con diets. The $\mathrm{N}$ input differences result from the differences observed in DMI because $\mathrm{N}$ concentration in the diet was similar among treatments. Retention of $\mathrm{N}$ was greater $(P<.05)$ in steers fed WCGF than in steers on the other two treatments (Table 5). Steers fed WCGF

Table 4. Dry matter intake, performance, and carcass characteristics of steers fed three finishing diets for $118 \mathrm{~d}$

\begin{tabular}{lcccc}
\hline \hline & \multicolumn{3}{c}{ Treatment $^{\mathrm{a}}$} \\
\cline { 2 - 4 } Item & WCGF & $7.5 \% \mathrm{R}$ & All Con & SEM \\
\hline Initial weight, $\mathrm{kg}$ & 337.2 & 335.9 & 336.7 & .8 \\
Final weight, $\mathrm{kg}$ & $549.2^{\mathrm{b}, \mathrm{e}}$ & $529.1^{\mathrm{c}, \mathrm{f}}$ & $521.4^{\mathrm{c}, \mathrm{g}}$ & 2.7 \\
DMI, kg/d & $12.32^{\mathrm{b}}$ & $11.59^{\mathrm{c}}$ & $10.41^{\mathrm{d}}$ & .12 \\
ADG, kg & $1.80^{\mathrm{b}, \mathrm{e}}$ & $1.64^{\mathrm{c}, \mathrm{f}}$ & $1.57^{\mathrm{c}, \mathrm{g}}$ & .02 \\
ADG:DMI & $.146^{\mathrm{b}, \mathrm{c}, \mathrm{e}}$ & $.141^{\mathrm{b}, \mathrm{f}}$ & $.151^{\mathrm{c}, \mathrm{g}}$ & .002 \\
Fat thickness, cm & 1.27 & 1.15 & 1.18 & .05 \\
Quality grade $^{\mathrm{h}}$ & 18.3 & 18.1 & 18.1 & .24 \\
\hline
\end{tabular}

${ }^{a}$ WCGF $=$ wet corn gluten feed diet; $7.5 \% \mathrm{R}=7.5 \%$ roughage diet; All Con = all-concentrate diet.

$b, c, d$ Means within a row with unlike superscripts differ $(P<.01)$.

e,f,gMeans within a row with unlike superscripts differ $(P<.10)$.

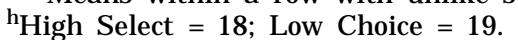


Table 5. Nitrogen mass balance in the feedlot based on $87 \mathrm{~d}$ in collection pens

\begin{tabular}{|c|c|c|c|c|c|c|c|}
\hline \multirow[b]{2}{*}{ Criterion $^{a}$} & \multicolumn{2}{|c|}{ WCGF $^{b}$} & \multicolumn{2}{|c|}{$7.5 \% \mathrm{R}^{\mathrm{b}}$} & \multicolumn{2}{|c|}{ All Con ${ }^{b}$} & \multirow{2}{*}{$\begin{array}{c}\text { SEM } \\
\mathrm{kg}\end{array}$} \\
\hline & $\mathrm{kg}^{\mathrm{c}}$ & $\%^{d}$ & $\mathrm{~kg}$ & $\%$ & $\mathrm{~kg}$ & $\%$ & \\
\hline Input & $22.92^{\mathrm{e}}$ & & $20.53^{f}$ & & $18.27^{f}$ & & .25 \\
\hline Retention & $2.09^{e}$ & & $2.03^{\mathrm{ef}}$ & & $1.98^{f}$ & & .02 \\
\hline Excreted & $20.83^{e}$ & & $18.50^{f}$ & & $16.29^{9}$ & & .25 \\
\hline Feces & $7.18^{e}$ & 34.5 & $5.35^{f}$ & 29.0 & $3.53^{\mathrm{g}}$ & 21.7 & .37 \\
\hline Urine & $13.65^{\mathrm{e}}$ & 65.5 & $13.15^{\mathrm{e}}$ & 71.0 & $12.76^{f}$ & 78.3 & .27 \\
\hline Removed & $3.89^{e}$ & 18.7 & $2.30^{f}$ & 12.4 & $1.45^{f}$ & 8.9 & .27 \\
\hline Soil & 2.06 & 9.9 & 3.03 & 16.4 & 2.38 & 14.6 & .41 \\
\hline Runoff & $.96^{\mathrm{e}}$ & 4.6 & $1.10^{\mathrm{e}}$ & 5.9 & $3.16^{f}$ & 19.4 & .27 \\
\hline Volatized & $13.92^{\mathrm{e}}$ & 66.8 & $12.07^{\mathrm{e}}$ & 65.3 & $9.30^{f}$ & 57.1 & .64 \\
\hline
\end{tabular}

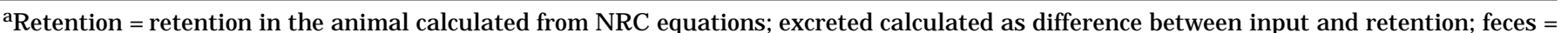
$\mathrm{N}$ excreted via feces calculated from DM excreted (from digestibility trial) multiplied by \%N in composited fecal samples; removed $=$ waste material removed from feedlot surface when pens cleaned; soil = balance of nitrogen in soil surface of pens.

bWCGF = wet corn gluten feed; $7.5 \% \mathrm{R}=7.5 \%$ roughage diet; All Con = all-concentrate diet.

${ }^{C}$ Kilograms of $\mathrm{N}$ per animal while in collection pens.

${ }^{\mathrm{d} A l l}$ values expressed as a percentage of $\mathrm{N}$ excreted.

e,f,gunlike superscripts within a row under the kilograms columns differ $(P<.01)$.

excreted more $(\mathrm{P}<.01)$ total $\mathrm{N}$ than steers fed $7.5 \%$ $R$. Steers fed the All Con diet excreted the least $(P<$ .01 ) total $\mathrm{N}$ when expressed as kilograms per animal. Based on DM digestibility determined in the digestibility trial and $\mathrm{N}$ concentration in feces for these three treatments, the steers fed WCGF excreted more ( $\mathrm{P}<$ .01) $\mathrm{N}$ in the feces than steers in the other two treatments. Similarly, steers on the $7.5 \% \mathrm{R}$ treatment excreted more $(\mathrm{P}<.01) \mathrm{N}$ in the feces than steers on the All Con treatment. Because $\mathrm{N}$ excretion was greater with steers fed WCGF, $\mathrm{N}$ excretion in the urine expressed as kilograms per day was similar ( $\mathrm{P}>$ .10) between WCGF and 7.5\% R treatments despite a lower percentage of $\mathrm{N}$ excretion via the urine with the WCGF treatment.

Nitrogen removed in the manure followed a pattern similar to that of fecal $N$ excretion: the most $(P<.01)$ $\mathrm{N}$ was removed from pens of steers on the WCGF treatment. When expressed as a percentage of total $\mathrm{N}$ excreted, $18.7,12.4$, and $8.9 \%$ of excreted $\mathrm{N}$ was removed in the manure for WCGF, $7.5 \% \mathrm{R}$, and All Con treatments, respectively. Nitrogen accumulating in the pen soil surface was not different $(P>.20)$ among treatments; 10 to $16 \%$ of excreted $\mathrm{N}$ remained on the pen surface after cleaning. More $\mathrm{N}$ was lost ( $\mathrm{P}$ $<.01$ ) from the pens on the All Con treatment in precipitation runoff.

Organic matter intake and excretion were highest $(P<.01)$ with steers fed WCGF, intermediate with $7.5 \% \mathrm{R}$, and lowest $(\mathrm{P}<.01)$ with the All Con treatment (Table 6). Organic matter removed in manure followed a pattern similar to that for OM excretion: 28 to $35 \%$ of excreted OM was removed in manure. Loss of OM in runoff was similar $(P>.10)$ for WCGF and $7.5 \% \mathrm{R}$, but more OM was lost ( $\mathrm{P}<$ .01) from the All Con pens during runoff events.

The WCGF treatment had the greatest $(P<.01)$ quantity and highest percentage of excreted nutrients $(\mathrm{N}$ and $\mathrm{OM}$ ) removed in manure when the pens were cleaned. The quantity of waste material removed from

Table 6. Organic matter mass balance in the feedlot based on $87 \mathrm{~d}$ in collection pens

\begin{tabular}{|c|c|c|c|c|c|c|c|}
\hline \multirow[b]{2}{*}{ Criterion $^{a}$} & \multicolumn{2}{|c|}{ WCGF } & \multicolumn{2}{|c|}{$7.5 \% \mathrm{R}^{\mathrm{b}}$} & \multicolumn{2}{|c|}{ All Con ${ }^{b}$} & \multirow{2}{*}{$\begin{array}{c}\text { SEM } \\
\mathrm{kg}\end{array}$} \\
\hline & $\mathrm{kg}^{\mathrm{c}}$ & $\%^{d}$ & $\mathrm{~kg}$ & $\%$ & $\mathrm{~kg}$ & $\%$ & \\
\hline Input & $1,059^{e}$ & & $981^{f}$ & & $854^{g}$ & & 12.0 \\
\hline Excreted & $269^{e}$ & & $172^{f}$ & & $114^{\mathrm{g}}$ & & 3.0 \\
\hline Removed & $93.6^{\mathrm{e}}$ & 34.8 & $55.9^{f}$ & 32.6 & $32.3^{\mathrm{g}}$ & 28.3 & 4.1 \\
\hline Soil & 94.9 & 35.3 & 93.7 & 54.5 & 55.5 & 48.5 & 15.7 \\
\hline Runoff & $7.1^{\mathrm{e}}$ & 2.7 & $6.3^{e}$ & 3.7 & $19.1^{f}$ & 16.7 & 1.8 \\
\hline Volatilized & $73.3^{\mathrm{e}}$ & 27.2 & $15.8^{f}$ & 9.2 & $7.5^{f}$ & 6.5 & 15.4 \\
\hline
\end{tabular}

${ }^{\mathrm{a}}$ Excreted calculated from DM excreted (from digestibility trial) multiplied by \%OM in composited fecal samples; Removed = waste material removed from feedlot surface when pens cleaned; soil = balance of organic matter in soil surface of pens.

bWCGF = wet corn gluten feed; $7.5 \% \mathrm{R}=7.5 \%$ roughage diet; All Con = all-concentrate diet.

CKilograms of OM per animal while in collection pens.

dAll values expressed as a percentage of OM excreted.

e,f,gunlike superscripts within a row under kilograms columns differ $(P<.01)$. 


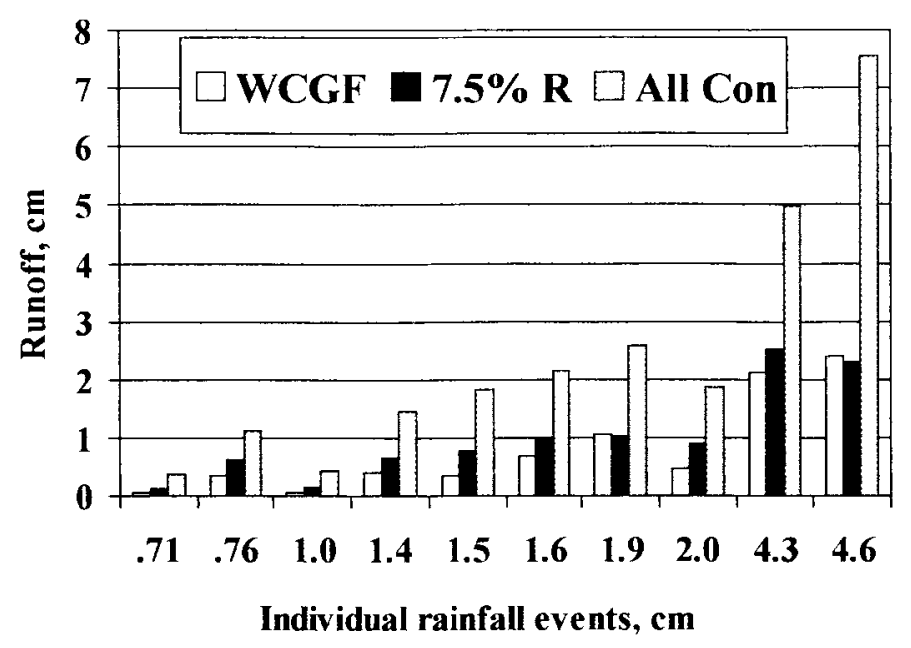

Figure 3. Quantity of runoff collected from pens during individual runoff events throughout $87 \mathrm{~d}$ while steers were in collection pens, where All Con $=$ all concentrate, $7.5 \% \mathrm{R}=7.5 \%$ roughage from corn silage and alfalfa, and WCGF $=41.5 \%$ corn gluten feed with roughage. Pens on the All Con treatment had a greater quantity of cumulative runoff than pens on the WCGF $(\mathrm{P}<.03)$ and $7.5 \% \mathrm{R}(\mathrm{P}<.09)$ treatments.

the feedlot was greatest for the WCGF treatment due to the increased amount of fecal output. The quantity of material removed when the pens were cleaned included waste material on top of the surface plus some soil. The quantity of manure removed for the WCGF, 7.5\% R, and All Con treatments were 232, 156, and $111 \mathrm{~kg}$ of DM per animal, respectively. The average quantity of material removed (166 $\pm 60 \mathrm{~kg}$ of DM per animal) was lower than the amount reported by Gilbertson et al. (1971), $318 \mathrm{~kg}$ of DM per animal. Gilbertson et al. (1971) fed a finishing diet and estimated digestibility as $75 \%$, which is comparable to our WCGF treatment. Gilbertson et al. (1971) had a greater stocking rate than that in this study, 18.6 vs $23.7 \mathrm{~m}^{2}$ per animal, and fed the cattle longer, 112 vs $87 \mathrm{~d}$. When comparing OM removed at cleaning, Gilbertson et al. (1971) estimated $121 \mathrm{~kg}$ of OM by assuming that $87 \%$ of feces was OM, whereas, in our study $94 \mathrm{~kg}$ of OM was removed for the WCGF treatment.

The All Con pens had a greater $(P<.01)$ quantity of cumulative runoff than the $7.5 \% \mathrm{R}$ and WCGF pens. Nitrogen and OM in runoff from pens on the All Con treatment were greater $(P<.01)$ than amounts in runoff from WCGF and 7.5\% R pens when expressed as kilograms per animal. Pens on the All Con diets had the greatest quantity of runoff because the pens had less fecal material to "trap" rainfall on the surface. Pens of steers on the $7.5 \% \mathrm{R}$ and WCGF treatments had a greater accumulation of fecal material on the feedlot surface, causing rainwater to pool. Variation in the quantity of individual runoff events was due to differences in the quantity of precipitation and degree of soil saturation prior to rainfall (Figure 3). Runoff from pens on the All Con treatment during some runoff events exceeded the centimeters of rain and suggests that some runoff may have entered those pens from the feed alley. Those pens had a driveway upslope and during rapid precipitation may have had some water enter from the driveway. The 7.5\% R and WCGF treatments resulted in 48.6 and $34.0 \%$, respectively, of the precipitation resulting in runoff, this is in agreement with the $48 \%$ determined by Gilbertson et al. (1971) and the 36\% observed by Clark et al. (1975). Significantly more runoff from the All Con treatment resulted in a higher percentage of nutrients in the runoff. The percentage of excreted $\mathrm{N}$ in runoff was 4.6, 5.9. and $19.4 \%$ for WCGF, 7.5\% R, and All Con treatments, respectively. Percentage of excreted OM in runoff ranged from 2.7 to $16.7 \%$. These percentages are in agreement with the 3 to $6 \%$ loss of excreted material in runoff reported by Gilbertson et al. (1971).

Steers consuming the WCGF diet had the greatest intake of nutrients due to greater DMI (Table 4). Subsequently, steers fed the WCGF diet excreted the most nutrients. Significantly more postruminal digestion of NDF occurs when a WCGF diet is fed compared to a dry-rolled corn diet (Larson, 1992). Thus, the higher fiber content of the WCGF diet apparently stimulated hindgut fermentation, causing an increase in the amount of fecal $\mathrm{N}$ excreted compared to $7.5 \% \mathrm{R}$ and All Con diets. When expressed as a percentage of total $\mathrm{N}$ excreted, percentage of $\mathrm{N}$ in feces ranged from 21.7 to 34.5 and percentage of $\mathrm{N}$ in urine ranged from 66 to $78 \%$; the WCGF treatment resulted in more fecal $\mathrm{N}$ and the All Con treatment resulted in more urinary $\mathrm{N}$ (Table 5). The proportion of excreted $\mathrm{N}$ in feces as a percentage of $\mathrm{N}$ intake (Figure 2) is lower than the distribution determined in the digestibility trial, probably due to difficulty in total collection of urine. If some urine was not collected, then the ratio in the feces would be overestimated. Therefore, the distribution of $\mathrm{N}$ in feces and urine in the feedl ot trial is based on measured $\mathrm{N}$ content of fecal samples.

The amount of $\mathrm{N}$ removed from the feedlot surface when pens were cleaned was $17.0,11.2$, and $7.8 \%$ of $\mathrm{N}$ intake for the WCGF, 7.5\% R, and All Con treatments, respectively. The values are lower than the 47 to $50 \%$ recovery of $\mathrm{N}$ input reported by Gilbertson et al. (1971) and Eghball and Power (1994). When the amount of $\mathrm{N}$ accumulated in soil was included in the quantity of $\mathrm{N}$ recovered, the percentage recovered was 26 for the WCGF and 7.5 R treatments and 21 for the All Con treatment. The discrepancy in recovery of $\mathrm{N}$ between this trial and past research may be due to the technique used to determine the values. In this experiment, the amount of excreted $\mathrm{N}$ was calculated using $\mathrm{N}$ intake and animal performance, whereas in the past the amount was estimated (ASAE, 1990). 


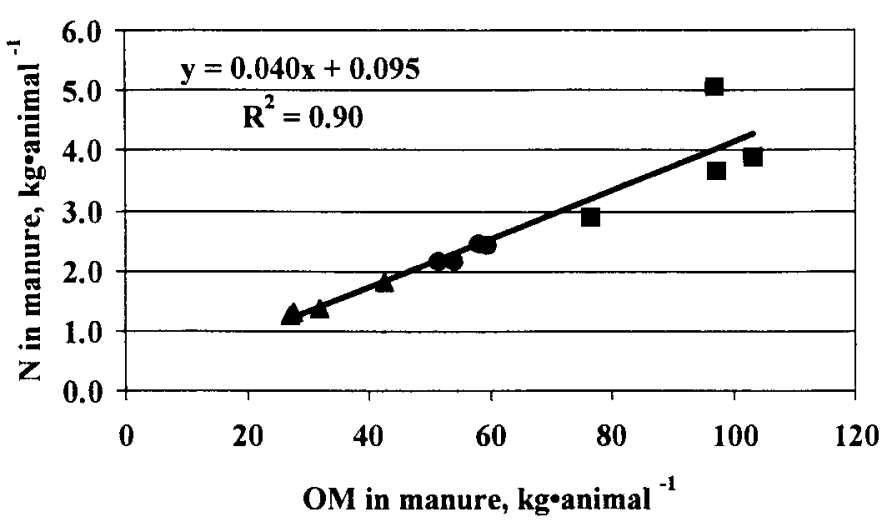

Figure 4. Relationship of manure $\mathrm{N}$ to manure $\mathrm{OM}$ expressed as kilograms/animal. $\mathbf{\Delta}=$ all concentrate, $\bullet=$ $7.5 \%$ roughage from corn silage and alfalfa, and $=$ $41.5 \%$ corn gluten feed. Each point represents a pen average.

This experiment was conducted from J une to October, whereas other research has addressed a full annual cycle. Recovery of $\mathrm{N}$ should be lower during the summer months due to greater ambient temperatures and better drying conditions (Hutchinson et al., 1982).

Volatilization losses were calculated by difference between the amount of nutrients excreted minus the amount removed from the pens, in the soil, and in the runoff. Overall, the WCGF treatment had a greater loss of $\mathrm{N}$ through volatilization because the pens were generally wetter than those of steers on the $7.5 \% \mathrm{R}$ and All Con treatments. A wet feedlot pen causes the surface to be anaerobic, reducing the amount of nitrification and subsequently increasing volatilization of $\mathrm{N}$ as ammonia (Hutchinson et al., 1982). Another indicator of anaerobic conditions in the WCGF pens is the low percentage of $\mathrm{N}$ in the soil. Past research has shown that nitrification in the feedlot occurs under dry, aerobic conditions (Elliot and McCalla, 1973; Hutchinson et al., 1982). Nitrate content of soil samples was determined and represented less than $.001 \%$ of the accumulated soil $\mathrm{N}$ for all treatments.

The significant amount of OM volatilized from pens on the WCGF treatment is probably related to the quantity of excreted OM. More OM was exposed to the environment and lost through volatilization. Regressing the amount of $\mathrm{N}$ recovered in manure with $\mathrm{OM}$ recovered in manure cleaned from the pens suggests a linear relationship between $\mathrm{N}$ retention in manure and amount of OM on the pen surface (Figure 4). The increased OM may lead to greater conversion of $\mathrm{N}$ from volatile forms such as ammonia to nonvolatile forms such as amino acids, similar to aerobic composting (Mackie et al., 1998). The percentage of excreted $\mathrm{N}$ that volatilized was 67,65 , and 57 for WCGF, $7.5 \%$ $\mathrm{R}$, and All Con, respectively. The amount of $\mathrm{N}$ volatilized per animal was greater for the WCGF and $7.5 \% \mathrm{R}$ treatments than for the All Con $(\mathrm{P}<.01)$ treatment. Nitrogen excretion for the All Con and $7.5 \% \mathrm{R}$ treatments was 4.5 and $2.3 \mathrm{~kg}$ less than that for the WCGF treatment.

Results from this experiment indicate that dietary fiber and carbohydrate source affect the amount of hindgut fermentation, resulting in different pathways for $\mathrm{N}$ excretion. The high NDF content of WCGF allowed more hindgut fermentation compared with the NDF content of $7.5 \% \mathrm{R}$ and All Con rations. The amount of fecal $\mathrm{N}$ and $\mathrm{OM}$ excreted per animal was greatest for the WCGF treatment due to the higher DMI coupled with the effect of decreased digestibility. The WCGF diet caused the steers to excrete more fecal material, thus a greater quantity of nutrients were removed from the feedlot surface. The linear increase in $\mathrm{OM}$ in manure with increased fiber in the diet resulted in greater $\mathrm{N}$ retention in manure.

\section{Implications}

Waste management is a crucial part of feedlot operations. Most feedlots use waste material as a fertilizer for crops. Thus, maximum retention of nitrogen on the feedlot surface is important to ensure an acceptable fertilizer. Feeding corn gluten feed may be expected to increase fecal output and result in more nitrogen and organic matter available for use as fertilizer. Diet composition affects the amount and composition of excreted material. Fiber, in the form of corn gluten feed, corn silage, and alfalfa hay may triple (190\% increase) organic matter removed in manure and increase the amount of nitrogen removed by $168 \%$.

\section{Literature Cited}

AOAC. 1996. Official Methods of Analysis (15th Ed.). Association of Official Analytical Chemists, Washington, DC.

ASAE. 1990. ASAE Data: ASAE D384.1 Manure Production and Characteristics. American Society of Agricultural Engineers, St. J oseph, MI.

Clark, R. N., A. D. Schneider, and B. A. Stewart. 1975. Analysis of runoff from southern great plains feedlots. Trans. ASAE 18(2): 319-322.

Eghball, B., and J. F. Power. 1994. Beef cattle feedlot manure management. J. Soil Water Cons. 49:113-122.

Elliott, L. F., and T. M. McCalla. 1973. The fate of nitrogen from animal wastes. In: Proc. Professional Conf. on Nitrogen in the Environment, Lincoln, NE. pp 86-110.

Giger-Reverdin, S., D. Suvant, J. Hervieu, and M. Dorleans. 1991. Fecal and urinary nitrogen losses as influenced by the diet carbohydrate and protein fractions in goats. In: Proc. 6th Int. Symp. Protein Metabolism and Nutrition, Herning, Denmark. pp 358-360.

Gilbertson, C. B., T. M. McCalla, J . R. Ellis, O. E. Cross, and W. R. Woods. 1971. Runoff, solid wastes, and nitrate movement in beef feedlots. J. Water Pollut. Contam. Fed. 43:483-493. 
Hutchinson, G. L., A. R. Mosier, and C. E. Andre. 1982. Ammonia and amine volatilization from a large cattle feedlot. J . Environ. Qual. 11:288-293.

Larson, E. M. 1992. Corn bByproducts for finishing cattle. M.S. thesis. Univ. of Nebraska, Lincoln.

Mackie, R. I., P. G. Stroot, and V. H. Varel. 1998. Biochemical identification and biological origin of key odor components in livestock waste. J. Anim. Sci. 76:1331-1342.

Mason, V. C., M. P. Narang, J . C. Ononiwu, and P. Kessank. 1977. The relationship between nitrogen metabolism in the hindgut and nitrogen excretion. Publ. Eur. Assoc. Anim. Prod. 22:61-63.

Mobley, H.L.T., and R. P. Hausinger. 1989. Microbial ureases: Significance, regulation, and molecular characterization. Microb. Rev. 53:85-108.
NRC. 1996. Nutrient Requirements of Beef Cattle (6th Ed.). National Academy Press, Washington, DC.

SAS. 1990. SAS User's Guide: Statistics. SAS Inst. Inc., Cary, NC. Ulyatt, M. J., D. W. Dellow, C.S.W. Reid, and T. Bauchop. 1975. Structure and function of the large intestine of ruminants. In: I. W. McDonald and A.C.I. Warner (Ed.) Digestion and Metabolism in the Ruminant: Proc. IV Int. Symp. Ruminant Physiology. pp 119-133. The University of New England Publishing Unit, Armidale, NSW, Australia.

Vanderholm, D. H. 1985. Nutrient losses from livestock waste during storage, treatment and handling. In: Livestock Waste Management Proc. Int. Symp. on Livestock Waste, ASAE, St. J oseph, MI. pp 395-398. 